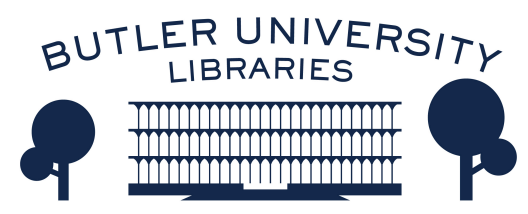

Journal of Hindu-Christian Studies

\title{
Book Review: Vernacular Catholicism, Vernacular Saints: Selva J. Raj on "Being Catholic the Tamil Way"
}

James Ponniah

University of Madras

Follow this and additional works at: https://digitalcommons.butler.edu/jhcs

Part of the Christianity Commons, Hindu Studies Commons, and the Religious Thought, Theology and Philosophy of Religion Commons

\section{Recommended Citation}

Ponniah, James (2017) "Book Review: Vernacular Catholicism, Vernacular Saints: Selva J. Raj on "Being Catholic the Tamil Way"," Journal of Hindu-Christian Studies: Vol. 30, Article 23.

Available at: https://doi.org/10.7825/2164-6279.1675

The Journal of Hindu-Christian Studies is a publication of the Society for Hindu-Christian Studies. The digital version is made available by Digital Commons @ Butler University. For questions about the Journal or the Society, please contact cbauman@butler.edu. For more information about Digital Commons @ Butler University, please contact digitalscholarship@butler.edu. 
efforts at inculturation have sometimes received amongst Hindus, since Aguilar's rich descriptions suggest an almost unmitigated acceptance. Nor would this book be the first port-of-call for readers looking for a philosophical 'history of ideas' (we do not really know, for example, why so many of the main characters specifically chose Advaita Vedānta as their main Hindu conversation partner), but the author is clear from the start that he is offering more of a 'contextual' than a philosophical approach. As such, he surely succeeds in giving us an exploration of "the idea and practice of an ashram", as well as "the history of a contemplative experience that...led to ground- breaking forms of Christian-Hindu dialogue" (25).

While it may be more accurate to nuance this summary of Aguilar's work by qualifying its 'Christian-Hindu' focus as being decidedly more Catholic and Vedāntic than anything else, he offers an exciting and thoroughly readable description of an "unexpected phenomenon" namely, that these five men whose "initial motivation was to bring Christianity closer to Indians...themselves became transformed into practitioners of both religions" (14).

Daniel Soars

University of Cambridge

\section{Vernacular Catholicism, Vernacular Saints: Selva J. Raj on "Being Catholic the Tamil Way." Edited by Reid B. Locklin. Albany, New York: State University of New York Press, 2017, xvii + 290 pages.}

VERNACULAR Catholicism, a posthumously published volume of Selva J. Raj's essays on Tamil Catholicism, is a dream come true as it brings to fruition the project of Raj himself, which was left incomplete due to his sudden demise in 2008. The fact that his American colleagues, especially Reid B. Locklin-the editor of the volume, would take it up and make the project see the light of the day speaks volumes for the high esteem Raj enjoyed among his American colleagues for his extraordinary scholarship on popular Indian Christianity. The book chapters unpack three important dimensions of Indian Christianity, especially of Tamil Catholicism, "namely "vernacular" Christianity grounded in mundane concerns, its cultural embeddness, and the ritual dialogue' (xvii), as noted by Raj in his book proposal.
These grounded themes of Indian Christianity, passionately explored and relentlessly espoused by Raj in his writings, were seldom noticed by the scholars of Indian religion. It is Raj's singular research commitment to the grass-root phenomena of Indian Christianity that has earned for common peoples' lived Christianity in India a good deal of academic credibility. Practice-centred lay people's Christianity, unlike elitist institutionalized forms of Indian Christianity, had long been unduly jettisoned as an irrational set of beliefs and superstitious practices. Raj's work was a timely intervention that not only filled the long existing void in the scholarship of Indian Christianity but also added news pieces to the jigsaw puzzle of the complex reality of Indian Christianity as a lived religion. 
The first chapter entitled 'Being Catholic the Tamil Way' is an autobiographical essay, a form of reflexive ethnography that shows how one's own personal experiences (in this case, Raj's engagement with Indian Christianity) can become a window to understand the larger cultural universe one is part of and the hybrid nature of Tamil Catholicism constructed through the processes of assimilation and differentiation. Part I of the volume entitled 'Vernacular Catholicism in Context' is a collection of three chapters; the first one by one of the famous Indian theologians, Prof. Michael Amaladoss, introduces to the readers the cultural story of Tamil Catholicism that covers a range of indigenization attempts, while the other two chapters by Raj unravels the threefold ritual strategies of popular indigenization (namely, inclusion, supplementation and traditionalization) as opposed to the triple models of institutional indigenization (namely, the missionary model, the monastic model and the liturgical model). As the editor perceptively notes, all three chapters in this section have a common denominator in that they describe the funeral traditions of Indian Catholicism and together they serve as a good source material for studying the organic wholes of funerary practices among Indian Christians who share many common dimensions with non-Christians in a given culture.

The second part of the volume, based on Raj's ethnographic works on three Catholic Christian shrines-St. John de Britto's shrine at Oriyur, St. Anne's shrine at Arulandapuram and St. Anthony's shrine at Uvari, draws the reader's attention to the complex ritual world of the Tamils and the central role it plays in pursuing the mundane well-being of lay Catholics and Hindus alike. True to its title, the essay on
'Shared vows, Shared space, and Shared Deities' dwells upon the range of vow rituals termed as nerccai in Tamil cultural idiom. Based on his insightful study on this ritual repertoire observed at the Catholic shrines, Raj not only concludes that 'the Catholic system retains the basic principles, idioms, vocabulary, content, and rubric of the Hindu system' (83) but also asserts that the nerccai system 'serve as an important intersection for the dialogue not only of rituals and devotees but of sites and deities as well' (84).

Part III of the volume that consists of chapters 8,9 and 10 delves deeply into the social dynamics of such Tamil cultural rituals as chaparam (car procession of the deity), baby auction, men's ritual-cooking and asanam (ritual meal). In these rituals, making use of Tom Driver's Turnerian insights, Raj highlights not only the collapse of borders between the sacred and sacrilegious, the serious and the playful but also the transgressive subversion these ritual practices produce. One of the significant contributions of this section is the idea of ritual dialogue wherein ritual is described 'as a medium for encountering the 'other' and a model for dialogue on a profoundly experiential and existential level' (189). Raj proposes this grassroots level 'dialogue on the ground' as an alternative to the 'contrived, structured, institutional dialogical initiatives engineered and pursued by the religious elite' (189). It seems to me that Raj's exploration into the social dynamics of the Tamil shrine-based rituals lends itself to employ Catherine Bell's understanding of ritual as a special kind of social practice that empowers the social actors with the privileged contrast to subvert hierarchy and to invert the social relations. 
Part IV of the book unfolds the relevance of Raj's works in the post-Selva period and includes chapters that celebrate Raj's contribution to the field of religious studies. Chapters 11,12, 13 and 14 stand as enduring examples which show how a scholar's ground-based notions and theoretical insights can be revisited and found by other scholars 'working in cognate fields' (xxi) as useful analytical tools to study other contexts, be it cultural (chapter 11 by Dempsey), ecclesial (chapter 12 by Kent) or trans-national (chapter 13 by Narayanan and Chapter 14 by Bilimoria).

This book is definitely a very compelling narrative of Tamil Catholicism written by Selva J. Raj-one of the greatest contemporary scholars of Indian Christianity-whose humanity and scholarship were perfectly blended to study the unstudied and to taste the waters of popular Christianity untouched by many others. But Raj deep-dived into the waters and drank it stomachful to quench his intellectual thirst and, in the process, produced very insightfully many such theoretical tropes as lay ecumenism, ritual dialogue, dialogue on the ground etc., that have become a trendsetting lens through which the lived-religion of the common folk in India would be looked at for many more years to come.

James Ponniah

University of Madras

\section{Ritual Participation and Interreligious Dialogue: Boundaries, Transgressions and Innovations. Edited by Marianne Moyaert and Joris Geldhof. London and New York: Bloomsbury, 2015. ix + 262 pages.}

RITUAL Participation and Interreligious Dialogue is a superb collection of essays addressing with boldness and acuity three turns in modern theology and the study of religion: the turn to religious practice in all its forms as a topic of study, attention to what people actually do, as distinct from theologies and rules about what ought to happen; sensitivity to the interplay of practice and theology, each influencing the other; a new sensitivity to the phenomenon of interreligious participation in religious practice.

This exploration of "the phenomenon of interreligious ritual participation" is shaped according to several categories noticed by Moyaert in her introduction: "types of ritual participation" (institutionally organized encounters; simpler instances of extending or receiving hospitality), "reasons for ritual participation" (by invitation; by family connections; for learning or in solidarity; personal spiritual journey); "shared belief as a precondition to inter-riting;" "the transformative power of ritual performance," as participation affects even faith commitment; "ritual as identity marker" (marking insider and outsider status); "changing patterns of religion" (when, for example, young people choose participation by subjectively guided choices).

The bulk of the volume divides into four sections: "philosophical, theological, and phenomenological observations," "Muslim and Christian-Muslim perspectives;" "Christian and East Asian Religious Perspectives" (a slight 